\title{
Gyökércsúcs rezekciója navigált endodontiai mikrosebészeti technikával
}

\author{
Nagy Eszter dr. - Fráter Márk dr. - Antal Márk dr.
}

Szegedi Tudományegyetem, Fogorvostudományi Kar, Konzerváló és Esztétikai Fogászati Tanszék, Szeged

\begin{abstract}
A modern fogászati implantológiában már rutinszerúen alkalmazott sebészi sablonok és háromdimenziós (3D) tervezőprogramok segítségével lehetőség nyílik más szakterületek fejlődésére is. Az operációs mikroszkóppal történő sebészeti gyökércsúcs-eltávolítás sokkal pontosabb rezekciót tesz lehetővé, ám a mútéti terület lokalizálására és méretének meghatározására nyomtatott sebészi sablonok alkalmazására még nincs konkrét ajánlás. Célunk egy új, sablonnal navigált mikrosebészeti gyökércsúcs-rezekciós technika bemutatása, melynek során a számítógépes programban megtervezett ostetotomiát és rezekciót egy körtrepánnal végezzük. A számítógépes programban (SMART Guide; dicomLAB, Szeged) cone-beam computed tomography (CBCT-) felvétel használatával 3D sablont készítünk, mellyel meghatározzuk a rezekciós ablak átmérőjét, a trepán behatolási mélységét és szögét. A teljes vastagságú lebeny kialakítását követően, a dentális megtámasztású, nyomtatott sablont a mútéti területre helyezve, a corticalis csont és a gyökércsúcs eltávolítása trepánnal történik. A mútéti beavatkozás a modern mikrosebészet elveit követi, ennek megfelelően az ultrahangos retrográd preparálást retrográd töméssel, 'mineral trioxide aggregate' (ProRoot MTA; Dentsply Maillefer, Ballaigues, Svájc) alkalmazásával zárjuk. A komplikációk nélkül lezajlott gyógyulási időszakot követő egyéves kontrollfelvételen a periapicalis laesio telődött, a páciens panaszmentes. A könnyen és nagy pontossággal végrehajtható beavatkozás utáni fájdalommentes gyógyulás mellett a technika nagy előnye, hogy maga a mútéti beavatkozás gyorsabb, mint a sablon és trepán nélküli mikrosebészeti rezekció.
\end{abstract}

Orv Hetil. 2020; 161(30): 1260-1265.

Kulcsszavak: navigált, mikrosebészet, trepán, sablon, endodontia

\section{Guided modern endodontic microsurgery by use of a trephine bur}

Surgical guides and three-dimensional (3D) planning softwares used in everyday dental implantology open new possibilities in other fields of dentistry. While using the operation microscope in endodontic microsurgery provides more precise apicectomy, there is still no consent on the exact localisation and size of the bony window to be prepared for this surgery. Our aim is to describe a new, guided endodontic microsurgery method when osteotomy and apicectomy are planned in a 3D software and performed with a trephine bur. Based on data from Cone Beam Computed Tomography, planning of the surgical guide was performed with a 3D planning software (Smart Guide, dicomLAB, Hungary) in order to define the size of the bony window, the angulation and the depth of the trephine bur during the apicectomy. After preparing a mucoperiosteal flap, with the help of the dentally supported surgical guide, the trephine bur removes the cortical bone and the apex of the root simultaniously. Following the modern microsurgical protocol, after performing the ultrasonic retrograde preparation, mineral trioxide aggregate (ProRoot MTA; Dentsply Maillefer, Ballaigues, Switzerland) is placed as a retrograde filling to close the resected area. After the uneventful healing period, a complete bony regeneration can be seen on the 1-year follow up X-ray. The patient is symptom-free. This technique is considered to be faster and more precise than the non-guided endodontic microsurgery carried out without the utilization of a trephine bur.

Keywords: guided, microsurgery, trephine, endodontic, surgical guide

Nagy E, Fráter M, Antal M. [Guided modern endodontic microsurgery by use of a trephine bur]. Orv Hetil. 2020; 161(30): 1260-1265.

(Beérkezett: 2020. március 4.; elfogadva: 2020. március 25.)

\section{Rövidítések}

3D = háromdimenziós; $\mathrm{CAD}=($ computer-aided design $)$ számí tógéppel segített tervezés; CAM = (computer-aided manufacturing) számítógéppel segített gyártás; $\mathrm{CBCT}=($ cone-beam com- puted tomography) kúpsugaras komputertomográfia; MTA = (mineral trioxide aggregate) ásványi/minerál-trioxid aggregátum; NSAID = (nonsteroidal anti-inflammatory drug $)$ nemszteroid gyulladáscsökkentő gyógyszer; SD = standard deviáció 
A modern diagnosztikus lehetőségek fejlődése és a legújabb fogászati fejlesztések utat nyitottak az utóbbi pár évtizedben rohamosan fejlődő és egyre nagyobb sikerrátával elvégzett endodontiai ellátásnak. Bár az ortográd irányból végzett endodontiai beavatkozások (gyökérkezelés és gyökértömés) az esetek 70-95\%-ában gyógyuláshoz vezetnek, a 'lege artis' ellátást követően is perzisztáló, gyógyulási potenciált nem mutató laesiók esetén szükség lehet a retrográd megközelítésre - a gyökércsúcs és a gyulladt periapicalis szövetek eltávolítására és ezáltal a fog megtartására. Az endodontiai kezelés sikertelenségének leggyakoribb oka, hogy az intracanalis biofilmet nem tudjuk mindenhonnan tökéletesen eltávolítani: megmunkálatlan csatornák, csatornarészletek, isthmusok lehetnek a rezervoárjai a bakteriális infekciónak. A sokkal ritkábban előforduló extraradicularis biofilm jelenléte is nagyban befolyásolja a gyökérkezelés vagy akár az újra-gyökérkezelés sikerességét, hiszen a periradicularis térben nem tudunk semmilyen kemomechanikai hatást elérni a gyökérkezelés során. Az így perzisztáló baktériumok (Actinomyces oris - 84,6\%) [1] által fenntartott krónikus gyulladás különböző panaszokkal járhat: fistula jelenléte a vestibulumban, tályogok, radiológiai elváltozás vagy akár szisztémás gyulladás. Erre a problémára jelent megoldást a gyökércsúcs eltávolítása mint utolsó lehetőség a fog megtartására és a gyökérkezelés utáni esetleges szövődmények megszüntetésére, melynek jelentősége nagyban felértékelődött. A periapicalis sebészet szükségessége bizonyos esetekben vitathatatlan [2], ám a beavatkozások sikerességének nagy szórása (4495\%) [3] és az operációs mikroszkópok elterjedése miatt mindenképp szülkségszerű volt a követendő technikák és szakmai irányelvek átgondolása, felülvizsgálata $[4,5]$. A Kim és mtsai által leírt minimálinvazív, modern endodontiai mikrosebészet az alapjaiban változtatta meg a periapicalis sebészethez való viszonyt, teret engedve a legújabb technikai újítások alkalmazásának a megtartó fogászatban. A megváltozott eszközpark fontos elemei az operációs mikroszkóp, a gyökércsúcs levágására használt piezoeszközök - melyek lehetővé teszik az új, 90 fokban végzett gyökércsúcs-rezekciót - és a retrográd gyökértömés elkészítéséhez használt MTA- vagy biokerámia anyagok. A modern megközelítés szerint már kisebb lebenyt alkalmazunk, a sebészi beavatkozás végig mikroszkópos nagyításban történik, ezzel javítva a vizuális kontrollt; a gyökércsúcs apicalis 3-4 mm-ének eltávolítását [6] követően, speciális ultrahangos eszközzel minimum $3 \mathrm{~mm}$ mélységben retrográd preparálást végezve, a retrográd gyökértömést MTA-val végezzük el. $\mathrm{Az}$ endodontiai sebészettel párhuzamosan fejlődő implantológia, a CBCT mindennapos elérhetősége új technikák kifejlesztését teszi lehetővé, melyek a beavatkozás egyszerúbbé tételét, a hibafaktor kiküszöbölését és rövidebb gyógyulási időt hivatottak elérni. Már a tervezési fázishoz is szükségesek a különböző felbontású és méretû CBCT-felvételek, illetve a számos, rendelkezésre álló tervezőszoftver, melyekkel háromdimenziós (3D) képet

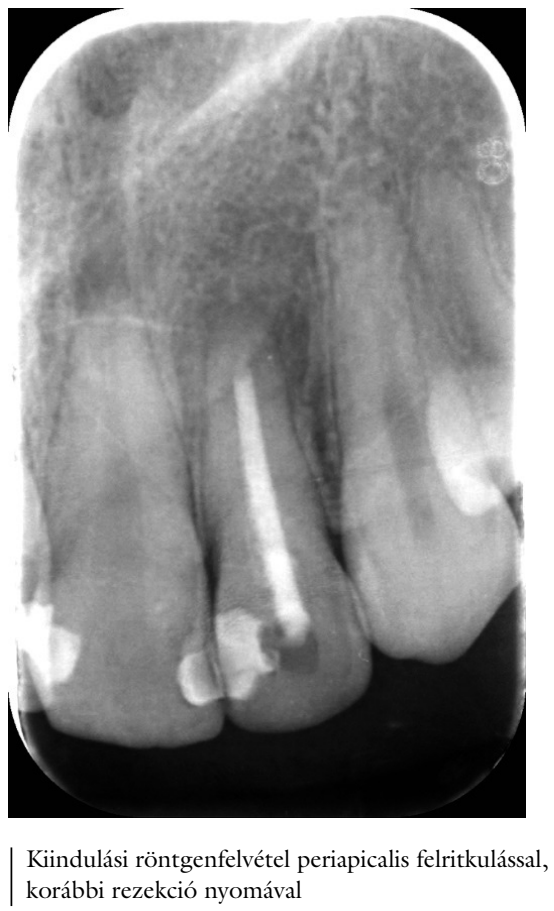

kaphatunk a mútéti területről, és megtervezhetjük magát a beavatkozást. A beavatkozást navigáló, 3D tervezett és 3D nyomtatott sablonok alkalmazásának elve pedig a fogászat minden területén azonos, ezáltal egyre elterjedtebbé válnak [7]. A két technikai vonal és egy új, trepánnal végzett rezekciós módszer ötvözését az alábbi esetbemutatással szemléltetjük.

A 26 éves hölgy páciens folyamatos érzékenységre panaszkodott a 22 -es fog gyökércsúcsi részénél. A klinikai és radiológia vizsgálat krónikus periapicalis gyulladást igazolt, optikailag korrekt gyökértömés megléte mellett (1. ábra). Az anamnézisben szerepelt egy korábbi gyökércsúcs-rezekció, melyet mikroszkóp használata nélkül, továbbá retrográd gyökértömés alkalmazása nélkül végeztek el, és nem eredményezett gyógyulást. A diagnózis és a kezelési terv felállításához CBCT-felvétel készült.

\section{Módszer}

\section{Sebészi sablon készitése}

Az egyénre szabott sebészi sablon elkészítéséhez a felső és alsó állcsontról orthodontiai kanállal (Hager \& Werken GmbH, Duisburg, Németország; 'size' 3) vett lenyomatokat (Orthoprint; Zhermack, Badia Polesine, Olaszország) kiöntés után harapásregisztrátum (O-Bite; DMG, Hamburg, Németország) segítségével artikuláltuk. Fényre kötő metakrilát egyéni kanál anyagot (Elite LC; Zhermack) adaptáltunk a mútéti területre, különös tekintettel a 22 -es fog gyökércsúcs-vestibulum régiójára, teljes interokklúzióban, ezzel segítve a sablon pontos pozicionálását. A radiológiai vizsgálatot megelőzően 6 kis guttaperchadarabot helyeztünk el az előre elkészített furatokba. A röntgensablonról és a páciensról, illetve a sab- 

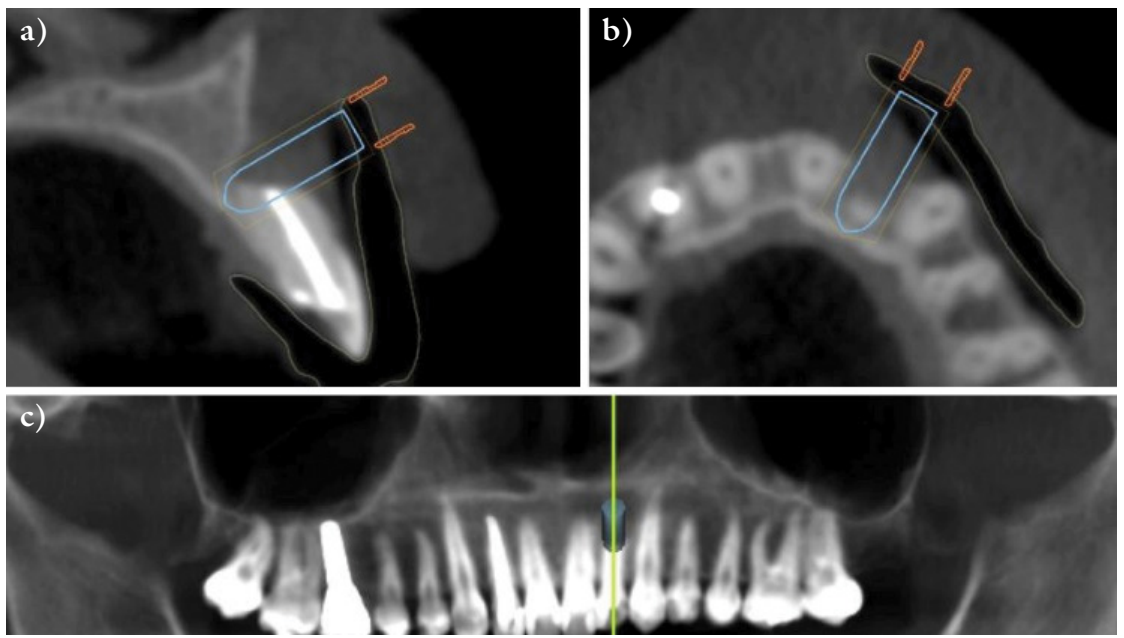

2. ábra |A behatolás szögének (a), mélységének (b) és a trepán átmérőjének (c) meghatározása a SMART Guide tervezőszoftver segítségével
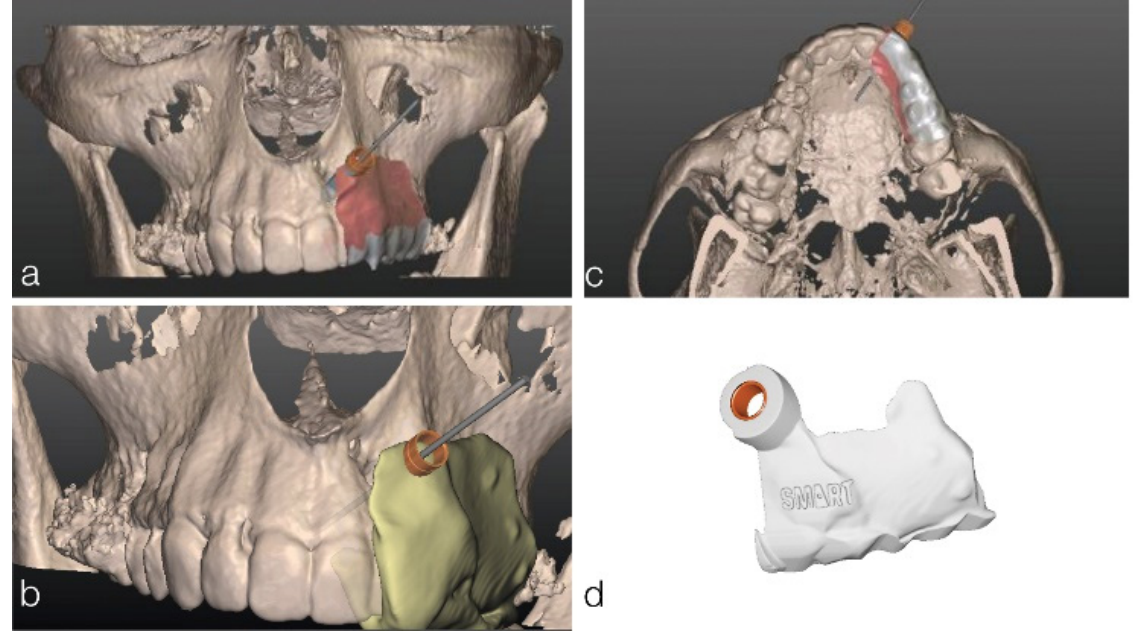

\begin{tabular}{l|l} 
3. ábra & A tervezett mútét modellezése 3D szoftver segítségével (a, b, c); sztereolitográfiás sablon (d)
\end{tabular}

lonról külön készített 2 CBCT-felvétel adatait egy 3D implantátumtervező programban (SMART Guide; dicomLAB, Szeged) összeregisztrálva szerkesztettük meg a sablont. Az osteotomiás ablak méretét a modern apicalis sebészeti elvek mellett az apex, a szomszédos anatómiai képletek elhelyezkedése és a trepán átmérője határozta meg. A behatolás szögét, mélységét és átmérőjét a navigált implantációs tervezőszoftverek ismert felhasználási lehetőségei és módszerei alapján terveztük meg (2. és 3. ábra). Az így kapott sablon sztereolitográfiás módszerrel készült el.

\section{Sebészi beavatkozás}

Az aktuális endodontiai mikrosebészeti elveket [8] követve, a beavatkozáshoz operációs mikroszkópot (OPMi pico2; Carl Zeiss AG, Oberkochen, Németország) és mikrosebészeti eszközöket, anyagokat használtunk. A bal felső kismetszőfog területét infiltrációs érzéstelenítéssel (Ultracain DS Forte 1 : 100 000; Sanofi Aventis, Párizs, Franciaország), és a korábban elkészült, dentális megtámasztású sablon kis perselyének megfelelően teljes vastag, szubmarginális lebennyel tártuk fel a 21-23-as fogak közötti területet (4. ábra). A csontablak helyét jelölő sablon tervezésekor a persely a trepán külső átmérőjéhez lett igazítva $(4,5 \mathrm{~mm}$; Hager \& Meisinger $\mathrm{GmbH}$, Neuss, Németország), míg a magasságát a behatolás kí-

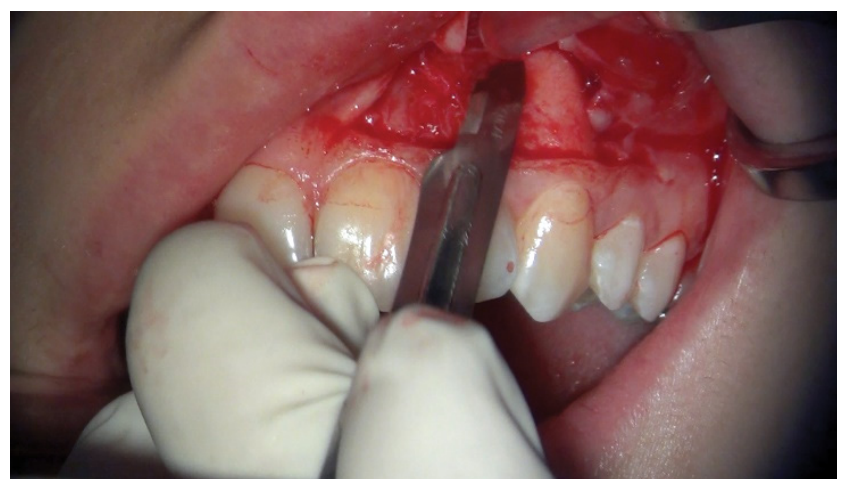

4. ábra $\quad$ Teljes vastagságú szubmarginális lebeny kialakítása a 21-23-as fogak régiójában 

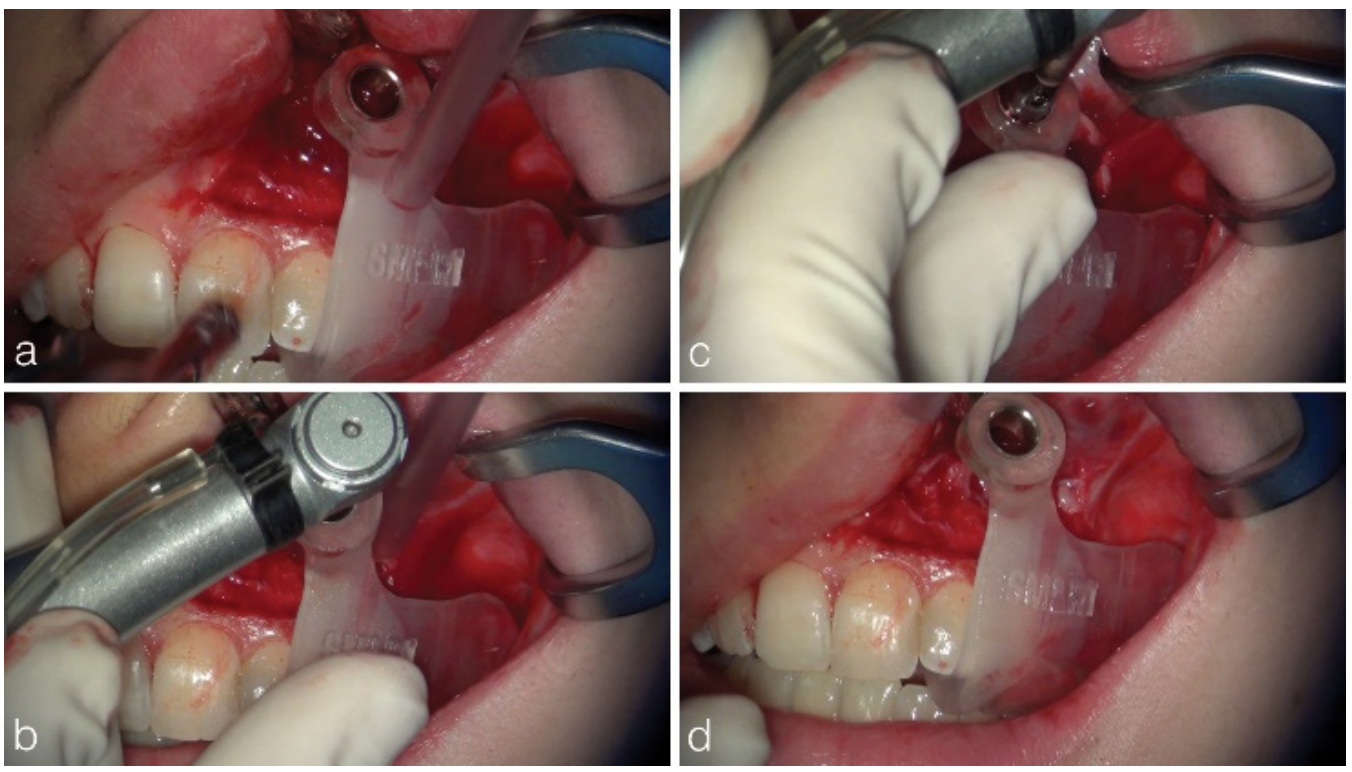

5. ábra

| Az interokklúzióban stabilizált mútéti sablon in situ (a), vízhútés mellett végzett mikrosebészeti rezekció trepánnal (b, c, d)

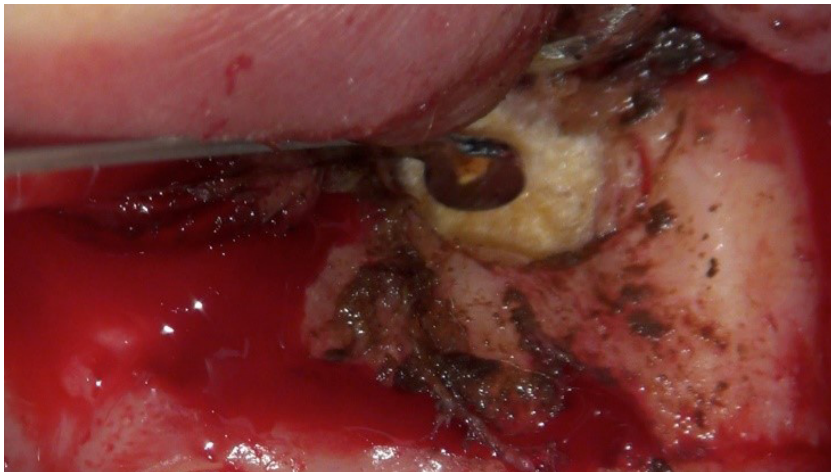

6. ábra

A rezekált gyökérfelszín vizsgálata mikrotükör segítségével: vasszulfátos vérzéscsillapítás után a gyökércsatornában látható guttapercha gyökértömés vánt mélysége és a trepán hossza határozta meg. A korábban megtervezett sablont megfelelő lágyrész-retrakció mellett felhelyezve és stabilizálva, az osteotomiát és a gyökércsúcs-rezekciót egy lépésben, megfelelő nyomaték és vízhűtés mellett (Implantmed; W\&H, Bürmoos, Ausztria) végeztük el (5. ábra), az így reszekált felszínt pedig operációs mikroszkóppal, 16-szoros nagyítás alatt, metilénkékfestés után vizsgáltuk. A gyulladt periapicalis szöveteket kürettel távolítottuk el. Vérzéscsillapítás céljából vas-szulfát-tartalmú oldatba (Astringedent 15,5\%; Ultradent Products Inc., South Jordan, UT, Amerikai Egyesült Államok) mártott vattagombócot használtunk (6. ábra). A retrográd preparáláshoz (7. ábra) Piezomed RID és R2RD hegveket (W\&H), a retrográd töméshez
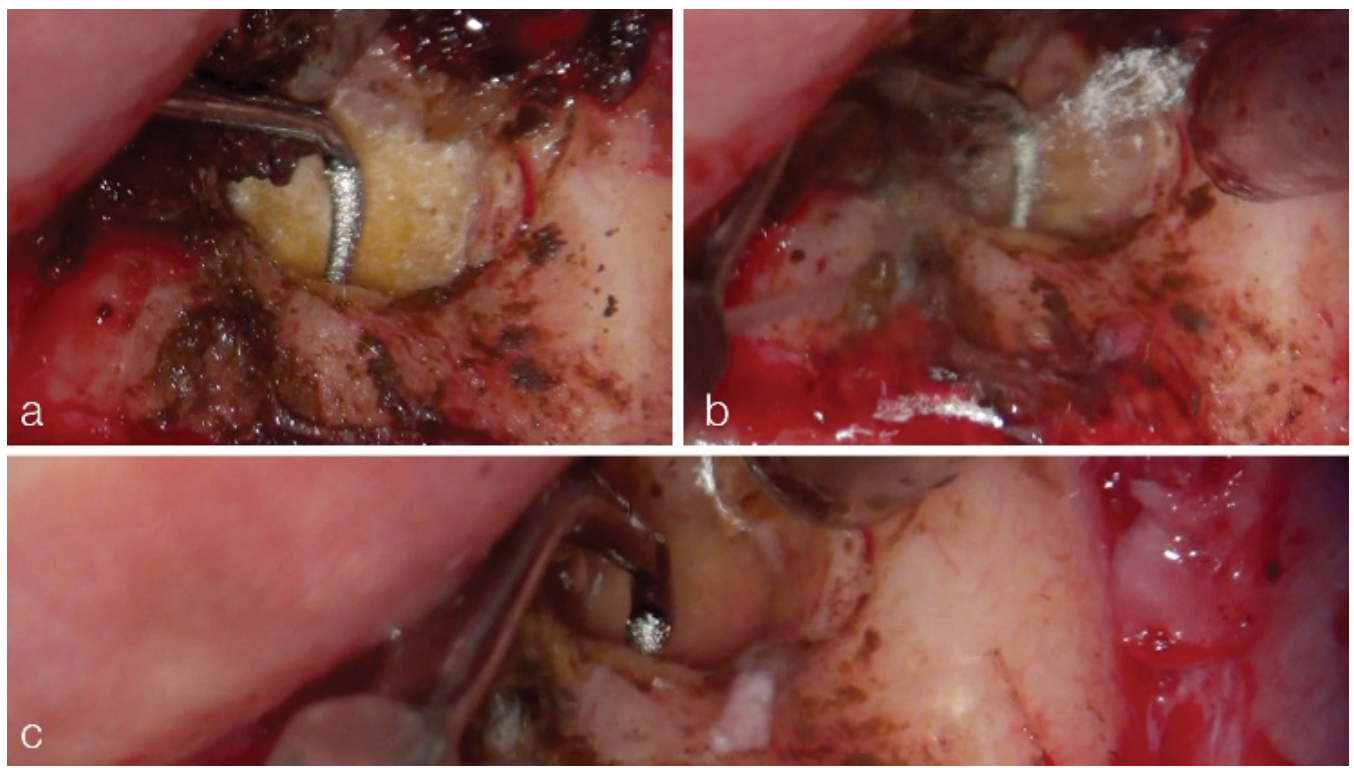

7. ábra $\quad$ Retrográd gyökércsatorna preparálása, vízhútés mellett $(\mathrm{a}, \mathrm{b}, \mathrm{c})$, piezoelektromos fejekkel (Piezomed, W\&H) 
pedig MTA-t használtunk (ProRoot MTA; Dentsply Maillefer, Ballaigues, Svájc) [9]. A csontfelszín vas-szulfáttól való megtisztítását és vérzés indukálását követően, a lebenyt sima csomós öltésekkel, nem felszívódó varrattal zártuk (Silkam 4/0; B. Braun, Melsungen, Németország). Posztoperatív röntgenfelvétel készült a beavatkozás pontosságának meghatározására és az eredmény dokumentálása céljából (8. ábra).

\section{Eredmények}

A páciens a mútétet követően gyors és fájdalommentes gyógyulásról számolt be. Panaszai elmúltak, a terület érzékenysége teljesen megszűnt. A beavatkozás után $1 \times 50$ mg diklofenák-kálium tartalmú NSAID (nonsteroidal anti-inflammatory drug) gyógyszer bevételét leszámítva a páciens nem érezte szükségét további gyógyszeres kiegé-

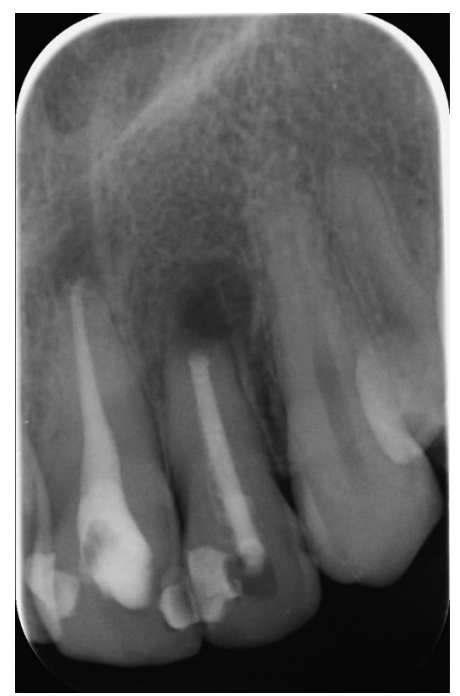

8. ábra

Jól kivehető a trepán által eltávolított, kör alakú radiolucens terület a posztoperatív röntgenfelvételen

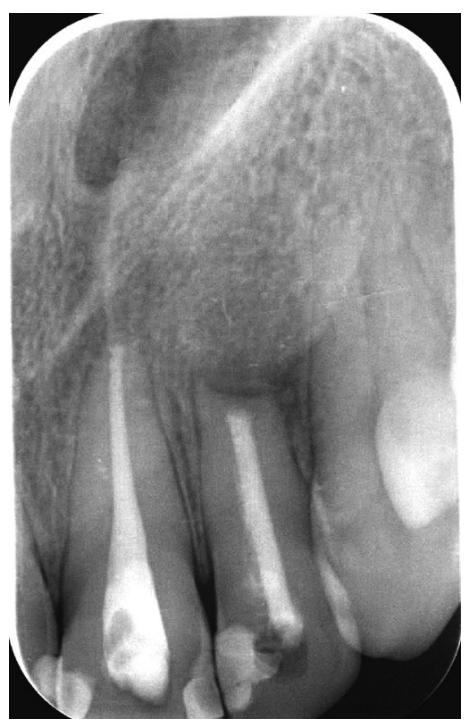

9. ábra

| Féléves kontrollfelvétel, csontos telódés a periapicalis részen szítő terápiának, antibiotikumot nem kapott. A 6 hónapos kontroll periapicalis felvételen (9. ábra) látszódik a mútött terület csontos telődése, a korábbi radiolucens laesio gyógyulása. Az 1 éves CBCT-felvételen a regenerálódott csontszerkezet megtartott, a páciens panaszmentes. A 3 éves kontroll periapicalis felvételen (10. ábra) látszódik a gyógyult periodontalis rés és a lamina dura rajzolata a lekerekedett rezekciós felszín körül, melyet a Molven és $m t$ sai $[10,11]$ által meghatározott 2 dimenziós radiológiai értékelés alapján teljes gyógyulásnak mondhatunk.

\section{Megbeszélés}

Az alkalmazott mütéttechnika érdekessége, hogy navigált sebészetet és trepánt alkalmaz a modern elveket követő, mikrosebészeti gyökércsúcs-rezekciónál. Az utóbbi években egyre jobban előtérbe kerülő 3D képalkotás és nyomtatott sablonok alkalmazási területe és módja még sokrétú, és nem adnak egységes képet, ám világossá vált, hogy a fogmegtartó kezelések irányába törekednek.

Pinsky és mtsai [12] 2007-es vizsgálata alapján a CAD/ CAM sablonnal végzett rezekciók pontossága az apextől $0,79 \mathrm{~mm}( \pm 0,33 \mathrm{SD})$, míg a szabad kézzel végzett furatok esetében 2,27 mm ( \pm 1,46 SD) volt. 10 évvel később, a sztereolitográfiás technikák fejlődésével előtérbe kerültek a navigált beavatkozások legkülönbözőbb formái. A periapicalis sebészetben először retraktorként alkalmazott sablon Patel [13] nevéhez füződik, ebben az esetben a jobb láthatóság és hozzáférés volt a cél. Strbac és mtsai [14] 2017-es közleményükben az osteotomiás ablakot és a behatolás mélységét is $3 \mathrm{D}$ tervezőprogram segítségével határozták meg, ám hagyományos rezekciót végeztek. A trepánnal végzett beavatkozásra 2018-ban Giacomino és mtsai [15] publikáltak egy esetsorozatot, mely a rövid posztoperatív nyomon követés ellenére is jól szemlélteti a technika lehetséges indikációs területeit. A navigált, trepánnal végzett beavatkozás biztosítja, hogy kizárólag a

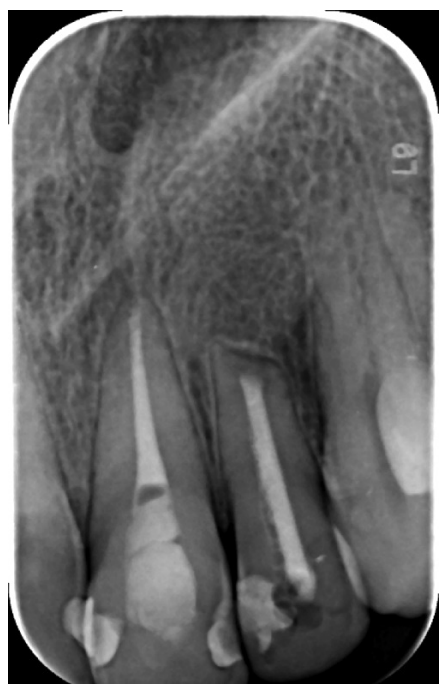

10. ábra $\mid$ Teljes gyógyulás: a lamina dura rajzolata és jól kivehetó, szabályos periodontalis rés a 3 éves kontrollröntgenen 
tervezőprogramban lokalizált területet érintsük, ezzel megóvva a környező anatómiai képletek épségét (nervus mentalis kilépése, arteria palatina major) és biztosítva a különleges anatómiai képletek magabiztos rezekcióját (összefekvő gyökércsúcsok, fuzionált gyökerek, dens in dente [16]). Továbbá a nehezen hozzáférhető területek (alsó molarisok) ellátása, a rezekálandó fog melletti implantált terület vagy a kiváló széli zárással rendelkező koronai restaurátum (korona/híd) megóvása indikálhatja még a megszokottnál költségesebb és komolyabb technikai háttért igénylő mikrosebészeti beavatkozást. Ezen esetekben kiemelt jelentősége van a precizitásnak és a páciens számára okozott anyagi, illetve pszichés kár minimalizálásának. A bemutatott eset egy korábbi rezekció korrekciós beavatkozása, emiatt fontos volt az optimális [17] korona-gyökér arány megtartására való törekvés és a precíz kivitelezés. A 3D tervezőprogram segítéségével pontosan meg lehet határozni a szükséges minimumot, mellyel az apicalis $3 \mathrm{~mm}$-t és ezzel az esetleges bakteriális reinfekció forrásaként jelen lévő gyökércsúcsi deltát vagy ramificatiókat tudjuk eltávolítani [18-20]. A lebenyképzés során figyelmet kell fordítani a szükséges minimális hozzáférés és a megfelelő vérellátás biztosítására, valamint a marginális gingiva integritásának megörzésére, melyek a gyors, per primam gyógyulást facilitálják, míg az intraossealis gyógyulást az osteotomiás ablak kiterjedése befolyásolja. A körtrepán használatával lehetőség nyílik az osteotomia és a rezekció egy időben történő elvégzésére, ami jelentősen meggyorsítja az atraumatikus mikrosebészeti beavatkozást.

\section{Következtetések}

A körtrepánnal történő apicalis, 3D navigált, mikrosebészeti rezekció precíz, relatíve könnyen kivitelezhető, gyors technikai megoldásnak tûnik. A módszernek, ha nem is a mindennapi fogászatban, de speciális esetekben látjuk indikációját, amikor különböző anatómiai variációk, képletek vagy meglévő fogpótlások akadályoznák az ortográd irányból történő beavatkozást. Az eseménytelen gyógyulási időszak, a hosszú nyomon követés során tapasztalt teljes gyógyulás és panaszmentesség a technika további, részletes vizsgálatára ösztönöz minket.

Anyagi támogatás: A szerzők anyagi támogatásban nem részesültek.

Szerzői munkamegosztás: N. E.: A cikk mútéttechnikai és érdemi részének megírása. A. M.: A cikk „ötletadója” és a digitális tervezéssel foglalkozó részének megírója, továbbá a mütét kivitelezője. F. M.: A szakmai tartalom ellenőrzője, a közlemény formázója. A cikk végleges változatát valamennyi szerző elolvasta és jóváhagyta.

Érdekeltségek: A szerzőknek nincsenek érdekeltségeik.

\section{Irodalom}

[1] Wang J, Jiang Y, Chen W, et al. Bacterial flora and extraradicular biofilm associated with the apical segment of teeth with posttreatment apical periodontitis. J Endod. 2012; 38: 954-959.

[2] Evans GE, Bishop K, Renton T. Update of guidelines for surgical endodontics - the position after ten years. Br Dent J. 2012; 212 : 497-498.

[3] Rahbaran S, Gilthorpe MS, Harrison SD, et al. Comparison of clinical outcome of periapical surgery in endodontic and oral surgery units of a teaching hospital: a retrospective study. Oral Surg Oral Med Oral Pathol Oral Radiol Endod. 2001; 91: 700-709.

[4] Setzer FC, Shah SB, Kohli MR, et al. Outcome of endodontic surgery: a meta-analysis of the literature - part 1: comparison of traditional root-end surgery and endodontic microsurgery. J Endod. 2010; 36: 1757-1765.

[5] Tsesis I, Faivishevsky, Kfir A, et al. Outcome of surgical endodontic treatment performed by a modern technique: a metaanalysis of the literature. J Endod. 2009; 35: 1505-1511.

[6] Kim S, Kratchman S. Modern endodontic surgery concepts and practice: a review. J Endod. 2006; 32: 601-623.

[7] Krastl G, Zehnder MS, Connert T, et al. Guided endodontics: a novel treatment approach for teeth with pulp canal calcification and apical pathology. Dent Traumatol. 2016; 32: 240-246.

[8] Floratos S, Kim S. Modern endodontic microsurgery concepts: a clinical update. Dent Clin North Am. 2017; 61: 81-91.

[9] Saunders WP. A prospective clinical study of periradicular surgery using mineral trioxide aggregate as a root-end filling. J Endod. 2008; 34: 660-665.

[10] Molven O, Halse A, Grung B. Observer strategy and the radiographic classification of healing after endodontic surgery. Int J Oral Maxillofac Surg. 1987; 16: 432-439.

[11] Molven O, Halse A, Grung B. Incomplete healing (scar tissue) after periapical surgery - radiographic findings 8 to 12 years after treatment. J Endod. 1996; 22: 264-268.

[12] Pinsky HM, Champleboux G, Sarment DP. Periapical surgery using CAD/CAM guidance: preclinical results. J Endod. 2007; 33: 148-151.

[13] Patel S, Aldowaisan A, Dawood A. A novel method for soft tissue retraction during periapical surgery using $3 \mathrm{D}$ technology: a case report. Int Endod J. 2017; 50: 813-822.

[14] Strbac GD, Schnappauf A, Giannis K, et al. Guided modern endodontic surgery: a novel approach for guided osteotomy and root resection. J Endod. 2017; 43: 496-501.

[15] Giacomino CM, Ray JJ, Wealleans JA. Targeted endodontic microsurgery: a novel approach to anatomically challenging scenarios using 3-dimensional-printed guides and trephine burs. A report of 3 cases. J Endod. 2018; 44: 671-677.

[16] Khayat B, Jouanny G. Microsurgical endodontics. Quintessence Publishing, Párizs, 2019.

[17] Grossmann Y, Sadan A. The prosthodontic concept of crown-toroot ratio: a review of the literature. J Prosthet Dent. 2005; 93: 559-562.

[18] Kim S. Principles of endodontic microsurgery. Dent Clin N Am. 1997; 41: 481-497.

[19] Gilheany PA, Figdor D, Tyas MJ. Apical dentin permeability and microleakage associated with root end resection and retrograde filling. J Endod. 1994; 20: 22-26.

[20] Antal M, Nagy E, Braunitzer G, et al. Accuracy and clinical safety of guided root end resection with a trephine: a case series. Head Face Med. 2019; 15: 30

(Antal Márk dr.,

Szeged, Tisza Lajos krt. 60-64., 6720 e-mail: antalmarkdr@gmail.com)

A cikk a Creative Commons Attribution 4.0 International License (https://creativecommons.org/licenses/by/4.0/) feltételei szerint publikált Open Access közlemény. (SID_1) 